\title{
Skutki podatkowe sprzedaży psów rasowych na gruncie podatku od czynności cywilnoprawnych
}

\section{Tax on consequences of civil law transactions of selling purebred dogs}

Streszczenie. Przedmiotem artykułu jest problematyka skutków podatkowych sprzedaży psów rasowych na gruncie podatku od czynności cywilnoprawnych. Na podstawie katalogu czynności podlegających opodatkowaniu podatkiem od czynności cywilnoprawnych oraz analizy przepisów ustawy o ochronie zwierząt i Kodeksu cywilnego przyjęto tezę, iż umowa sprzedaży psa rasowego, jako czynność cywilnoprawna, podlega opodatkowaniu podatkiem od czynności cywilnoprawnych. Przedmiotem opodatkowania podatkiem od czynności cywilnoprawnych jest bowiem m.in. umowa sprzedaży rzeczy, a w sprawach nieuregulowanych w ustawie o ochronie zwierząt (w zakresie nieuregulowanym znajduje się m.in. właśnie kwestia obrotu zwierzętami) do zwierząt stosuje się odpowiednio przepisy dotyczące rzeczy. Podkreślono kwestię, istotną w kontekście przedmiotu opodatkowania, braku legalnej definicji „psa rasowego”. Wątpliwości może budzić natomiast ustalenie kryteriów, które pozwolą na jednoznaczne określenie, 
kiedy mamy do czynienia z psem rasowym, ze względu na wspomniany brak zdefiniowania tego pojęcia w obowiązujących przepisach. W badaniach zastosowano metodę formalno-dogmatyczną.

Słowa kluczowe: podatek; czynność cywilnoprawna; pies rasowy; sprzedaż; umowa.

Abstract. This article is focused on tax on consequences of civil law transactions of selling purebred dogs. The analysis is based on the catalogue of activities which are subject to taxation under the tax on civil law transactions and provisions of the Animal Protection Act and the Civil Code. The Author claims that the contract for the sale of a purebred dog, a contract which is a civil law transaction, falls under the tax on civil law transactions. The subject of taxation with the tax on civil law transactions is, inter alia, a contract for the sale of goods and in matters not regulated in the Animal Protection Act (in the unregulated area there is, among others, an issue of trade in animals) the provisions on things shall apply accordingly to animals. In this article a lack of a legal definition of "purebred dog” - an issue important in the context of the subject of taxation - was also highlighted. However, due to the aforementioned lack of a definition doubts may arise when establishing criteria that will allow for an unambiguous determination when we are dealing with a purebred dog. In this text, a formal and dogmatic method was used in the research.

Keywords: tax; civil law transaction; purebred dog; sale; contract.

\section{Wprowadzenie}

Celem artykułu jest ustalenie, czy sprzedaż psa rasowego podlega opodatkowaniu podatkiem od czynności cywilnoprawnych. Tak postawiony problem badawczy wymaga po pierwsze zestawienia katalogu czynności podlegających opodatkowaniu tym podatkiem z przepisami mającymi zastosowanie do obrotu żywymi zwierzętami. Konieczne wydaje się wobec powyższego ustalenie, w jakim zakresie zastosowanie w rozważanym przypadku znajdą regulacje Kodeksu cywilnego ${ }^{1}$ dotyczące umów sprze-

1 Ustawa z dnia 23 kwietnia 1964 r. Kodeks cywilny (tekst jedn. Dz.U. z 2020 r. poz. 1740), dalej: k.c. 
daży, oraz zasygnalizowanie problemu braku definicji legalnej psa rasowego w obowiązujących przepisach. Poczynione rozważania zakończone zostały przedstawieniem wniosków. Badania przeprowadzono przy wykorzystaniu metody formalno-dogmatycznej ${ }^{2}$. Zakres i znaczenie opracowania może wydawać się marginalne, jednakże problem dotyczy opodatkowania minimum kilkudziesięciu tysięcy umów sprzedaży w skali roku

\section{Opodatkowanie czynności cywilnoprawnych w kontekście sprzedaży psa rasowego - zarys problematyki}

Zgodnie z art. 1 ust. 1 pkt 1 lit. a ustawy o podatku od czynności cywilnoprawnych $^{4}$ przedmiotem opodatkowania tym podatkiem jest umowa sprzedaży oraz zamiany rzeczy i praw majątkowych. Artykuł 1 ust. 4 u.p.c.c. stanowi, że czynności cywilnoprawne podlegają podatkowi, z zastrzeżeniem ust. 4a i $5^{5}$ u.p.c.c., jeżeli ich przedmiotem są rzeczy znajdujące się na terytorium Rzeczypospolitej Polskiej lub prawa majątkowe wykonywane na terytorium Rzeczypospolitej Polskiej oraz rzeczy znajdujące się za granicą lub prawa majątkowe wykonywane za granicą, w przypadku gdy nabywca ma miejsce zamieszkania lub siedzibę na terytorium Rzeczypospolitej Polskiej i czynność cywilnoprawna została dokonana na terytorium Rzeczypospolitej Polskiej.

Umowa sprzedaży na gruncie u.p.c.c. powinna być rozumiana w znaczeniu przyjętym $\mathrm{w}$ prawie cywilnym ${ }^{6}$. Zgodnie $\mathrm{z}$ art. 6 ust. 1 pkt 1

2 Prezentowane zagadnienie było przedmiotem interpretacji indywidualnej prawa podatkowego. Pismo z dnia 6 czerwca 2012 r. wydane przez Izbę Skarbową w Katowicach, IBPBII/1/436-60/12/MZ - Określenie skutków podatkowych umów sprzedaży psów (szczeniąt).

3 W 2019 r. w Związku Kynologicznym w Polsce zarejestrowano ponad 50000 urodzonych szczeniąt, http://www.zkwp.pl/1.tmp/index.php/ct-menu-item-28/57-zestawieniahodowlane/1556-zestawienie-hodowlane-2019.html (dostęp: 20.04.2021 r.).

4 Ustawa z dnia 9 września 2000 r. o podatku od czynności cywilnoprawnych (tekst jedn. Dz.U. z 2020 r. poz. 815 ze zm.), dalej: u.p.p.c.

5 Przepisy te dotyczą opodatkowania umowy zamiany oraz umowy spółki.

6 Z. Ofiarski, Komentarz do art. 1 ustawy o podatku od czynności cywilnoprawnych [w:] Ustawa o opłacie skarbowej. Ustawa o podatku od czynności cywilnoprawnych. 
u.p.c.c. podstawę opodatkowania przy umowie sprzedaży stanowi wartość rynkowa rzeczy lub prawa majątkowego ${ }^{7}$. Artykuł 6 ust. 2 u.p.c.c. natomiast stanowi, że wartość rynkową określa się na podstawie przeciętnych cen przedmiotu czynności cywilnoprawnych stosowanych w obrocie rzeczami tego samego rodzaju i gatunku, z uwzględnieniem ich miejsca położenia, stanu i stopnia zużycia, oraz w obrocie prawami majątkowymi tego samego rodzaju, z dnia dokonania tej czynności, bez odliczania długów i ciężarów.

Do czynników wpływających na cenę psa rasowego, a zatem mających wpływ na podstawę opodatkowania podatkiem od czynności cywilnoprawnych, zalicza się w szczególności: rasę psa, jego pochodzenie (tytuły wystawowe, wyniki badań w kierunku schorzeń typowych dla danej rasy, wyszkolenie rodziców), płeć, wiek, predyspozycje wystawowe, w niektórych rasach także umaszczenie. Tytułem przykładu: dobrze rokujące wystawowo kilkumiesięczne szczenię po wymianie zębów (z prawidłowym zgryzem) będzie zdecydowanie droższe niż szczenię wydane kupującemu w wieku kilku-/kilkunastu tygodni (zależnie od rasy) posiadające wadę dyskwalifikującą z wystaw.

Stawka podatku od czynności cywilnoprawnych wynosi $2 \%$. O powstaniu obowiązku uiszczenia podatku od czynności cywilnoprawnej decyduje, na podstawie art. 3 ust. 1 pkt 1 u.p.c.c., moment dokonania czynności cywilnoprawnej ${ }^{8}$. Umowa sprzedaży zostaje zawarta w chwili

Komentarz, Wolters Kluwer 2018, LEX/el. (dostęp: 15.04.2021 r.). Tak też np. M. Waluga, Ustawa o podatku od czynności cywilnoprawnych. Komentarz, Warszawa 2009, s. 23-24. Por. B. Brzeziński, Prawo podatkowe a prawo cywilne, „Toruński Rocznik Podatkowy”, 2008 s. 132; B. Brzeziński, Wykładnia prawa podatkowego, Gdańsk 2013, s. 63-82; A. Halasz, Stosowanie definicji pojęć prawnych w prawie podatkowym - w poszukiwaniu woli ustawodawcy, „Przegląd Prawa i Administracji” 2020, nr 1 (120), s. 599-608; A. Halasz, Stosowanie definicji pojęć prawnych a zasada pewności w prawie podatkowym [w:] A. Gorgol (red.), Teoretyczne i praktyczne aspekty prawa finansowego. Problemy, koncepcje, wyzwania i rozwiqzania, Warszawa 2020, s. 189-196.

$7 \quad$ Na temat wartości rynkowej szerzej: R. Bernat, Sposób określenia wartości rynkowej w podatku od czynności cywilnoprawnych, „Zeszyty Naukowe Uniwersytetu Szczecińskiego” 2015, nr 861, s. 79-91.

8 Czynność prawna - rozumiana jako stan faktyczny - jest dokonana z chwilą realizacji wszystkich elementów tego stanu. W przypadku umów sprzedaży - jako czynności 
złożenia dwóch zgodnych oświadczeń woli sprzedawcy i kupującego. W przypadku podatku od czynności cywilnoprawnych każda czynność podlegająca opodatkowaniu rodzi równocześnie obowiązek podatkowy i zobowiązanie podatkowe ${ }^{9}$. Jest to zobowiązanie powstające w sposób określony w art. $21 \S 1$ pkt 1 Ordynacji podatkowej ${ }^{10}$, czyli z dniem zaistnienia zdarzenia, z którym ustawa podatkowa wiąże powstanie takiego zobowiązania (z mocy prawa). Zobowiązanie podatkowe powstaje wówczas bez konieczności dokonywania jakichkolwiek czynności przez strony stosunku prawnopodatkowego - innymi słowy „automatycznie”, bez względu na wolę i zamiar podatnika ${ }^{11}$. Obowiązek podatkowy przy umowie sprzedaży ciąży na kupującym. Termin „dokonanie” w przypadku umowy sprzedaży oznacza moment zawarcia umowy, który następuje w chwili złożenia zgodnych oświadczeń woli stron ze względu na fakt, że umowa sprzedaży należy do umów konsensualnych ${ }^{12}$.

Intencją ustawodawcy było opodatkowanie czynności niewadliwych, czyli ważnie dokonanych ${ }^{13}$, a zatem w przypadku uiszczenia podatku od bezwzględnie nieważnej czynności cywilnoprawnej ${ }^{14}$ mamy do czynienia z nadpłatą w rozumieniu art. $72 \S 1$ o.p. Podatnik może wówczas doma-

cywilnoprawnych, stosownie do art. 1 ust. 1 pkt 1 lit. a u.p.c.c. - obowiązek podatkowy w podatku od czynności cywilnoprawnych powstaje z momentem ich zawarcia. Wyrok WSA w Szczecinie z dnia 21 lutego 2018 r., I SA/Sz 1098/17, LEX nr 2460004.

9 Por. R. Mastalski, Glosa do wyroku SN z 18.05.2001 r., III RN 95/00, „Orzecznictwo Sądów Polskich” 2002, nr 5, LEX/el. (dostęp: 16.04.2021 r.).

10 Ustawa z dnia 29 sierpnia 1997 r. Ordynacja podatkowa (tekst jedn. Dz.U. z 2020 r. poz. 1325 ze zm.), dalej: o.p.

11 L. Etel, Komentarz do art. 21 [w:] R. Dowgier, P. Pietrasz, M. Popławski, S. Presnarowicz, W. Stachurski, K. Teszner, L. Etel, Ordynacja podatkowa. Komentarz, Wolters Kluwer 2017, LEX/el. (dostęp: 13.01.2021 r.).

12 Wyrok WSA w Białymstoku z dnia 6 października 2015 r., I SA/Bk 343/15, LEX nr 1940644 za: Z. Ofiarski, Komentarz do art. 3 ustawy o podatku od czynności cywilnoprawnych [w:] Ustawa o opłacie skarbowej. Ustawa o podatku od czynności cywilnoprawnych. Komentarz, Warszawa 2018, LEX/el. (dostęp: 5.01.2021 r.).

13 M. Goettel, A. Goettel, Podatek od czynności cywilnoprawnych. Komentarz, Warszawa 2007, s. 34.

14 Na temat skutków wadliwości czynności cywilnoprawnych na gruncie prawa podatkowego por. K. Radzikowski, Prawnopodatkowe skutki wadliwości czynności cywilnoprawnych, Warszawa 2015, LEX/el. (dostęp: 16.04.2021 r.). 
gać się zwrotu na podstawie przepisów o.p. o stwierdzeniu nadpłaty ${ }^{15}$. Jeżeli czynność prawna jest nieważna z mocą wsteczną (od chwili jej zawarcia), to znaczy, że nie może wywołać jakichkolwiek skutków prawnych zarówno w zakresie prawa cywilnego, jak i w sferze prawa podatkowego (powstanie zobowiązania podatkowego w podatku od czynności cywilnoprawnych) ${ }^{16}$.

Podsumowując, ważnie dokonana czynność sprzedaży psa ${ }^{17}$ podlega opodatkowaniu podatkiem od czynności cywilnoprawnych na podstawie art. 1 ust. 1 pkt 1 lit. a u.p.c.c.

\section{Zasady obrotu żywymi zwierzętami}

Stosownie do treści art. 1 ustawy z o ochronie zwierzą ${ }^{18}$ zwierzę, jako istota żyjąca, zdolna do odczuwania cierpienia, nie jest rzeczą, a człowiek jest mu winien poszanowanie, ochronę i opiekę. Rzecz została zdefiniowana w art. 45 k.c. jako przedmiot materialny. Nie budzi wątpliwości fakt, że od dnia wejścia w życie OchrZwU zwierzę, na podstawie art. 1 ust.1 tej ustawy, nie jest rzeczą w rozumieniu art. 45 k.c. Psy, co do zasa$\mathrm{dy}^{19}$, zaliczyć należy do zwierząt domowych ${ }^{20}$, czyli tradycyjnie przebywających wraz z człowiekiem w jego domu lub innym odpowiednim pomieszczeniu, utrzymywane przez człowieka w charakterze jego towarzysza (art. 4 ust. 17 OchrZwU). W sprawach nieuregulowanych w OchrZwU do zwierząt stosuje się odpowiednio przepisy dotyczące rzeczy -

15 Szerzej na ten temat: P. Skalimowski, Podatkowe skutki nieważności czynności prawnej, , Toruński Rocznik Podatkowy” 2011, s. 20-59, http://www.trp.umk.pl/download/ trp2011/Podatkowe_skutki_niewaznosci_czynnosci_prawnej_P_Skalimowski.pdf (dostęp: 26.02.2021 r.).

16 Wyrok WSA w Poznaniu z dnia 5 grudnia 2012 r., III SA/Po 813/12, LEX nr 1234672.

17 Artykuł 2 u.p.c.c. zawiera katalog wyłączeń przedmiotowych z opodatkowania.

18 Ustawa z dnia 21 sierpnia 1997 r. o ochronie zwierząt (tekst jedn. Dz.U. z 2020 r. poz. 638), dalej: OchrZwU.

19 Z wyjątkiem zwierząt wykorzystywanych do celów specjalnych, o których stanowi art. 4 ust. 20 OchrZwU.

20 O pojęciu zwierząt domowych por. wyrok NSA z dnia 23 lipca 2019 r., II OSK 2299/17, LEX nr 3073627, Wyrok NSA z dnia 18 lutego 2014 r., II OSK 2746/13, LEX nr 1450914. 
OchrZwU nie reguluje bowiem kwestii obrotu zwierzętami, w tym sprzedaży zwierząt.

Wobec powyższego zastosowanie w tym zakresie znajdują przepisy k.c. Odpowiednie stosowanie ${ }^{21}$ będzie dotyczyło przede wszystkim sytuacji prawnorzeczowej zwierząt i obrotu nimi ${ }^{22}$. W rozważanym przypadku stosowanie odpowiednie będzie tożsame ze stosowaniem przepisów wprost. OchrZwU nie zawiera bowiem przepisów szczególnych, które wymagałyby uwzględnienia przy odpowiednim stosowaniu przepisów dotyczących sprzedaży rzeczy. Ustawodawca poprzez regulacje OchrZwU, a przede wszystkim art. 1, stanowiący, iż zwierzę nie jest rzeczą, chciał zagwarantować humanitarne traktowanie zwierząt. Nie było natomiast ich celem przyznanie ich właścicielom specjalnych przywilejów podatkowych ${ }^{23}$, gdyż tego rodzaju rozwiązania musiałyby znaleźć odzwierciedlenie w przepisach podatkowych ${ }^{24}$.

Ustawa o podatku od czynności cywilnoprawnych również nie zawiera przepisów szczególnych, wyłączających lub modyfikujących przepisy w odniesieniu do sprzedaży psów. Mając na uwadze powyższe, to przepisy dotyczące rzeczy należy stosować do tego typu umów wprost ${ }^{25}$. Brak bowiem przeciwwskazań, aby przepisy odnoszące się do podlegających opodatkowaniu czynności i zdarzeń, które dotyczą rzeczy, stosować również wprost w stosunku do takich czynności i zdarzeń, których elementem są zwierzęta, tym bardziej, iż takiemu działaniu nie stoją na prze-

21 Por. M. Hauser, Odpowiednie stosowanie przepisów prawa - uwagi porzqdkujace, „Przegląd Prawa i Administracji”, t. 65, Wrocław 2005, s. 152; uchwała SN z 28 września 2006 r., I KZP 8/06, „Orzecznictwo Sądu Najwyższego Izba Karna i Wojskowa” 2006, nr 10, poz. 87.

22 Por. K. Skowrońska-Bocian [w:] K. Pietrzykowski (red.), Kodeks cywilny. Komentarz, t. I, Warszawa 1999, s. 137.

$23 \mathrm{Na}$ temat relacji pojęć przywilejów podatkowych i preferencji podatkowych por. K. Święch-Kujawska, Preferencje podatkowe jako element lokalnej polityki podatkowej - na przykładzie opodatkowania przedsiębiorców podatkiem od nieruchomości, „Finanse, Rynki Finansowe, Ubezpieczenia” 2017, nr 3 (87), cz. 2, s. 90.

24 Wyrok WSA w Warszawie z dnia 5 października 2009, III SA/Wa 615/09, Centralna Baza Orzeczeń Sądów Administracyjnych (CBOSA). Sprawa dotyczyła sprzedaży koni.

25 Odpowiednie zastosowanie przepisu może polegać na jego zastosowaniu wprost, zastosowaniu z odpowiednimi modyfikacjami lub na odmowie jego zastosowania ze względu na występujące różnice. Por. L. Morawski, Zasady wykładni prawa, Toruń 2006, s. 215. 
szkodzie przepisy k.c. dotyczące rzeczy ${ }^{26}$. W rozważanym zakresie, wobec odesłania do odpowiedniego stosowania do zwierząt przepisów o rzeczach, nie występuje także zjawisko luki w prawie ${ }^{27}$.

\section{Umowa sprzedaży psa}

Umowa sprzedaży została uregulowana w art. 535 i n. k.c. Przez umowę sprzedaży sprzedawca zobowiązuje się przenieść na kupującego własność $^{28}$ rzeczy i wydać mu rzecz, a kupujący zobowiązuje się rzecz odebrać i zapłacić sprzedawcy cenę. Sprzedaż jest umową wzajemną. Świadczenie sprzedawcy polega na przeniesieniu na kupującego prawa własności rzeczy, a świadczenie kupującego wyrażone jest za pomocą ceny ${ }^{29}$. Do umowy sprzedaży zastosowanie znajdują przepisy dotyczące zobowiązań wzajemnych ${ }^{30}$.

Ze względu na specyfikę umowy sprzedaży psa, określa się przedmiot umowy poprzez wskazanie rasy, pochodzenia (imion i przydomków rodziców), numeru identyfikacyjnego - tatuażu bądź chipa - oraz imienia i przydomka. W praktyce, poza postanowieniami wymaganymi dla zakwalifikowania umowy jako sprzedaży, w tego typu umowach zamieszcza się oświadczenia zarówno hodowcy, jak i kupującego o dobrej kondycji ${ }^{31}$

26 Powoływany już wyrok WSA w Warszawie z dnia 5 października 2009, III SA/Wa $615 / 09$.

27 Wyrok NSA z dnia 31 maja 2011, II FSK 77/10, CBOSA.

28 Na temat „własności” zwierząt por. podrozdział Koncepcja „własności” zwierzq̨t po wejściu w życie ustawy o ochronie zwierzq̨ [w:] M. Goettel, Sytuacja zwierzęcia w prawie cywilnym, Warszawa 2013, s. 59-60.

29 Szerzej nt. essentialia negotii umowy sprzedaży por. wyrok SN z 5 lutego 2002 r., II CKN 726/00, LEX nr 521911; wyrok SA w Białymstoku z dnia 11 lutego 2015 r., I ACa 769/14, LEX nr 1665064, wyrok SA w Warszawie z dnia 17 września 2020 r., VII AGa 1928/18, LEX nr 3115670.

30 A. Kozioł, Komentarz do art. 535 [w:] M. Fras, M. Habdas (red.), Kodeks cywilny. Komentarz. Tom IV. Zobowiqzania. Część szczególna (art. 535-764(9)), Wolters Kluwer 2018, LEX/el. (dostęp: 1.12.2020 r.).

31 Hodowca odpowiada za wady fizyczne psa na zasadach rękojmi, por. np. wyrok SO w Olsztynie z dnia 11 grudnia 2017 r., IX Ca 803/17, http://orzeczenia.olsztyn.so.gov.pl/ content/\$N/150515000004503_IX_Ca_000803_2017_Uz_2017-12-11_002, dostęp: 2.12.2020 r. Często spotyka się dodatkowe zapisy umowne o treści „,wady w uzębieniu lub inne niewidoczne w momencie wydania psa, a także brak uzyskania oceny dosko- 
nabywanego szczenięcia. Standardowo wśród postanowień umowy sprzedaży psa znajduje się także oświadczenie hodowcy, że odbył się przegląd miotu $^{32}$, a kupujący ma możliwość wglądu do protokołu przeglądu miotu, oraz że pies został poddany odrobaczeniu i szczepieniom zgodnie ze stosownymi wpisami w książeczce zdrowia. Hodowcy zabezpieczają interesy szczeniąt poprzez zobowiązanie kupującego do informowania o przebiegu rozwoju psa oraz okresowego wysyłania jego fotografii, jednocześnie zobowiązując kupującego do zapewnienia odpowiedniego żywienia psa, pielęgnacji i opieki weterynaryjnej oraz warunków bytowych, natomiast w przypadku chęci zbycia lub oddania psa do poinformowania o tym fakcie hodowcy.

\section{Pojęcie psa rasowego}

W aktualnie obowiązujących przepisach nie obowiązuje definicja legalna psa rasowego. W projekcie ustawy o zmianie ustawy o ochronie zwierząt i niektórych innych ustaw z dnia 11 września 2020 r. ${ }^{33}$ zaproponowano jej wprowadzenie. Zgodnie z projektem przez psa rasowego rozumie się psa o odpowiednim dla rasy fenotypie, który posiada rodowód wpisany do Polskiej Księgi Rodowodowej prowadzonej przez Związek Kynologiczny w Polsce albo do zagranicznego rejestru rodowodowego uznawanego przez ten związek. Nowelizacja ${ }^{34}$ OchrZwU, która weszła w życie 1 stycznia 2012 r., miała na celu ograniczenie niekontrolowanego rozmnażania psów. Przede wszystkim intencją ustawodawcy było zniwelowanie tej praktyki dotyczącej psów w typie popularnych ras. W artykule 10a ust. 2 OchrZwU wprowadzono wówczas zakaz rozmnażania psów i kotów w celach handlowych. Ustęp 6 tego przepisu wyłączył spod zakresu jego

nałej na wystawie nie stanowią podstawy do zwrotu psa lub innych roszczeń z tego tytułu”.

32 Zgodnie z Regulaminem Hodowli Psów Rasowych Związku Kynologicznego w Polsce.

33 Druk sejmowy nr 597 Poselski projekt ustawy o zmianie ustawy o ochronie zwierząt oraz niektórych innych ustaw, http://www.sejm.gov.pl/sejm9.nsf/druk.xsp?nr=597, (dostęp: 30.09.2020 r.).

34 Ustawa z dnia 16 września 2011 r. o zmianie ustawy o ochronie zwierząt oraz ustawy o utrzymaniu czystości porządku w gminach (Dz.U. z 2011 r. Nr 230, poz. 1373). 
stosowania hodowle zwierząt zarejestrowane w ogólnokrajowych organizacjach społecznych, których statutowym celem jest działalność związana z hodowlą rasowych psów i kotów. Ustawodawca nie określił natomiast standardów dla tego rodzaju organizacji. W szybkim tempie zaczęto rejestrować stowarzyszenia ${ }^{35}$ w celu spełnienia kryterium formalnego. Dotychczasowy podział na psy „, rodowodem” i „bez rodowodu” stracił na znaczeniu, ponieważ psy pochodzące z hodowli zrzeszonych w innych niż Związek Kynologiczny w Polsce w rozumieniu OchrZwU posiadają rodowody.

Mając na uwadze kwestie definicyjne, warto zauważyć, że w Prawie łowieckim ${ }^{36}$ ustawodawca posłużył się terminem „chartów rasowych lub ich mieszańców”. Artykuł 10 Prawa łowieckiego stanowi o hodowli chartów, jednakże na gruncie tego aktu prawnego nie zdefiniowano, jaki pies uznawany jest za charta rasowego. W piśmiennictwie wskazuje się, że ze względu na brak sprecyzowania tej kwestii przez ustawodawcę należy przyjąć, że nawet niewielka domieszka cech psa tej rasy jest wystarczająca, aby konieczne było uzyskanie zezwolenia na jego hodowlę lub utrzymanie $^{37}$.

Kolejnym aktem prawnym, w którym odwołano się do pojęcia rasy psa, jest Rozporządzenie Ministra Spraw Wewnętrznych i Administracji z dnia 28 kwietnia 2003 r. w sprawie wykazu ras psów uznawanych za agresywne $^{38}$. W kontekście projektowanej definicji psa rasowego, zakładającej odniesienie do regulacji ZKwP należącego do FCI, należy wskazać na sytuację zamieszczenia $\mathrm{w}$ wykazie ras nieuznanych przez FCI

35 Obecnie funkcjonuje kilkadziesiąt takich organizacji.

36 Ustawa z dnia 13 października 1995 r. Prawo łowieckie (tekst jedn. Dz.U. z 2020 r. poz. 1683).

37 A. Pązik, Komentarz do art. 10 [w:] M. Słomski, A. Pązik, Prawo łowieckie. Komentarz, Wolters Kluwer 2015, LEX/el. (dostęp: 5.01.2020 r.). Na podstawie delegacji wynikającej z art. 10 ust. 2 ustawy wydane zostało rozporządzenie Ministra Rolnictwa i Rozwoju Wsi z dnia 5 lipca 2010 r. w sprawie warunków i sposobu hodowania i utrzymywania chartów rasowych oraz ich mieszańców (Dz.U. Nr 135, poz. 909).

38 Rozporządzenie Ministra Spraw Wewnętrznych i Administracji z dnia 28 kwietnia 2003 r. w sprawie wykazu ras psów uznawanych za agresywne (Dz.U. Nr 77, poz. 687). 
(amerykański pit bull terier, akbash dog, anatolian karabash ${ }^{39}$, moskiewski stróżujący ${ }^{40}$ ) oraz niejednolitą terminologię, która nie pokrywa się z systematyką ras $\mathrm{FCI}^{41}$.

\section{Wnioski}

Po przeprowadzonej analizie przepisów prawa, mając na uwadze, że przedmiotem opodatkowania podatkiem od czynności cywilnoprawnych jest m.in. umowa sprzedaży rzeczy, a w sprawach nieuregulowanych w OchrZwU (do których zalicza się m.in. właśnie kwestia obrotu zwierzętami) do zwierząt stosuje się odpowiednio przepisy k.c. dotyczące rzeczy, należy stwierdzić, że ważnie zawarta umowa sprzedaży psa rasowego podlega opodatkowaniu tym podatkiem.

De lege ferenda zasadne wydaje się wprowadzenie definicji legalnej „psa rasowego” i przyjęcie określonej systematyki ras. Wątpliwości w praktyce budzi bowiem ustalenie kryteriów, które pozwoliłyby na jednoznaczne określenie, jakiego psa można uznać za psa rasowego. Na gruncie poruszanej problematyki ma to istotne znaczenie, bowiem konsekwencją określenia, czy dany pies jest psem rasowym, jest wskazanie, czy zgodnie z obowiązującymi przepisami może być „rozmnażany w celach handlowych”, a w dalszej kolejności - czy w związku z powyższym konkretna umowa sprzedaży podlega opodatkowaniu podatkiem od czynności cywilnoprawnych.

39 Od 2018 r. rasom anatolian i kangal FCI nadało wspólną nazwę kangal. Ustalono nowy wzorzec rasy, który stopniowo wyeliminuje anatoliany niespełniające wymogów standardu, http://www.anatolian.pl/index.php?option=com_content\&task=view\&id=32\& Itemid=34 (dostęp: 2.02.2021 r.). Wzorzec dostępny jest pod adresem: http://www.fci.be/en/nomenclature/KANGAL-SHEPHERD-DOG-331.html (dostęp: 2.02.2021 r).

40 Rosyjska Federacja Kynologiczna podjęła starania o zarejestrowanie rasy w FCI.

41 Szerzej na ten temat M. Duraj, Rasy niebezpieczne psów w prawie polskim i w prawie niektórych landów niemieckich, „Przegląd Prawa Publicznego” 2012, nr 11, s. 32-46. 


\section{Bibliografia:}

Bernat R., Sposób określenia wartości rynkowej w podatku od czynności cywilnoprawnych, „Zeszyty Naukowe Uniwersytetu Szczecińskiego” 2015, nr 861, s. 79-91.

Brzeziński B., Prawo podatkowe a prawo cywilne, „Toruński Rocznik Podatkowy”, 2008, s. 115-140.

Brzeziński B., Wykładnia prawa podatkowego, ODDK, Gdańsk 2013.

Duraj M., Rasy niebezpieczne psów w prawie polskim i w prawie niektórych landów niemieckich, „Przegląd Prawa Publicznego” 2012, nr 11, s. 32-46.

Etel L., Komentarz do art. 21 [w:] R. Dowgier, P. Pietrasz, M. Popławski, S. Presnarowicz, W. Stachurski, K. Teszner, L. Etel, Ordynacja podatkowa. Komentarz, Wolters Kluwer, 2017, LEX/el.

Goettel, A. Goettel, Podatek od czynności cywilnoprawnych. Komentarz, Wolters Kluwer, Warszawa 2007.

M. Goettel, Sytuacja zwierzęcia w prawie cywilnym, Wolters Kluwer, Warszawa 2013.

Halasz A., Stosowanie definicji pojęć prawnych w prawie podatkowym - w poszukiwaniu woli ustawodawcy, „Przegląd Prawa i Administracji” 2020, nr 1 (120), s. 599-608.

Halasz A., Stosowanie definicji pojęć prawnych a zasada pewności w prawie podatkowym [w:] A. Gorgol (red.), Teoretyczne i praktyczne aspekty prawa finansowego. Problemy, koncepcje, wyzwania i rozwiqzania, C.H. Beck, Warszawa 2020.

Hauser M., Odpowiednie stosowanie przepisów prawa - uwagi porzq̨dkujq̨ce, „Przegląd Prawa i Administracji”, t. 65, Wrocław 2005, s. 151-168.

Kozioł A., Komentarz do art. 535 [w:] M. Fras, M. Habdas (red.), Kodeks cywilny. Komentarz. Tom IV. Zobowiqzzania. Część szczególna (art. 535-764(9)), Wolters Kluwer 2018, LEX /el.

Mastalski R., Glosa do wyroku SN z 18.05.2001 r., III RN 95/00, „Orzecznictwo Sądów Polskich” 2002, nr 5, LEX /el.

Morawski L., Zasady wykładni prawa, TNOIK, Toruń 2006.

Ofiarski Z., Komentarz do art. 1, komentarz do art. 3 ustawy o podatku od czynności cywilnoprawnych [w:] Ustawa o opłacie skarbowej. Ustawa o podatku od czynności cywilnoprawnych. Komentarz, Wolters Kluwer 2018, LEX /el.

Pązik A., Komentarz do art. 10 [w:] M. Słomski, A. Pązik, Prawo łowieckie. Komentarz, Wolters Kluwer, Warszawa 2015, LEX /el. 
Radzikowski K., Prawnopodatkowe skutki wadliwości czynności cywilnoprawnych, Wolters Kluwer 2015, LEX /el.

Skalimowski P., Podatkowe skutki nieważności czynności prawnej, „Toruński Rocznik Podatkowy” 2011, s. 20-59.

Skowrońska-Bocian K. [w:] Kodeks cywilny. Komentarz, t. I, K. Pietrzykowski (red.), C.H. Beck, Warszawa 1999.

Święch-Kujawska K., Preferencje podatkowe jako element lokalnej polityki podatkowej - na przykładzie opodatkowania przedsiębiorców podatkiem od nieruchomości, „Finanse, Rynki Finansowe, Ubezpieczenia” 2017, nr 3 (87), cz. 2, s. 88-99.

Waluga M., Ustawa o podatku od czynności cywilnoprawnych. Komentarz, LexisNexis, Warszawa 2009. 